\title{
The Role of Patent Law in KNowledge CODIFICATION
}

\author{
By Dan L. Burk ${ }^{\dagger}$
}

\section{TABLE OF CONTENTS}

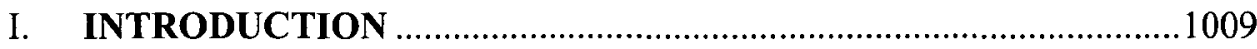

II. THE ECONOMICS OF CODIFICATION ……..................................1012

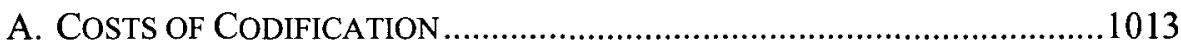

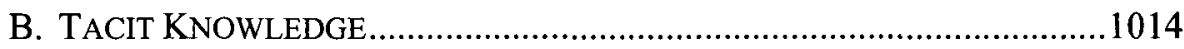

C. CONSEQUENCES OF CODIFICATION ................................................1016

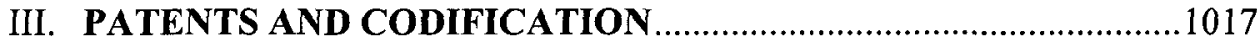

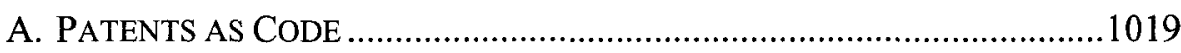

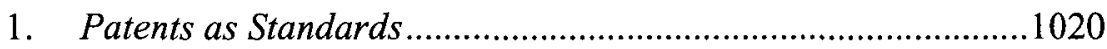

2. Disclosure Provisions ............................................................1021

B. TACIT KNOWLEDGE IN THE PRIOR ART............................................1024

C. CODIFYING CONCEPTION ...........................................................1028

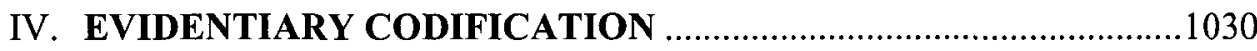

V. CODIFICATION AND PATENT REFORM ……………………........1032

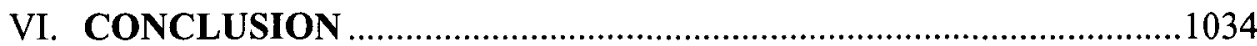

\section{INTRODUCTION}

Patents are problematic. The justification for patenting is less than clear. The grant of exclusive rights ${ }^{1}$ in a given technology clearly confers a potential benefit on the rights holder, but equally clearly creates an impediment to others who might wish to employ that technology. In the United States, the constitution authorizes Congress to implement a patent system in order to "promote the Progress of . . . useful Arts." But whether patents in fact promote progress, whether such progress is worth the cost,

(C) 2008 Dan L. Burk.

$\dagger$ Chancellor's Professor of Law, University of California, Irvine.

1. 35 U.S.C. $\$ 271$ (a) (2000).

2. U.S. ConST. art. I, $\S 1$, cl. 8; Graham v. John Deere Co., 383 U.S. 1, 5 (1966). 
and under what circumstances, remains the subject of extended, ongoing debate. $^{3}$

The rationale for patenting long favored in judicial opinion is the "quid pro quo" theory: that patents are a bargain of sorts, between the inventor and the public, exchanging public disclosure of the claimed invention in return for the grant of a period of exclusive rights. ${ }^{4}$ But this explanation has never been entirely satisfactory. As a practical matter, patents are not production documents, and a good deal of the information that the technical community might like to divine from them is either accidentally or purposefully left out of the published patent. ${ }^{5}$ Additionally, it is unclear why an innovator would opt to trade disclosure of an invention for less than twenty years of exclusivity, when the alternative of keeping the invention as a trade secret is available in perpetuity. ${ }^{6}$ Of course, some inventions cannot be kept confidential enough to be maintained as trade secrets, but in those cases the patent bargain exchanges exclusivity for the disclosure of something that was bound to become public anyway.

Given the difficulties in the disclosure rationale, the dominant justification for the patent system has shifted toward an economic rationale based upon incentives. Under this prevalent view, the grant of exclusive rights deters quick imitation of the claimed invention and allows a period of supernormal profits that help to recoup the investment made in developing the invention. ${ }^{8}$ The incentive rationale reasons that innovators will be more likely to make an investment in new technologies if they know beforehand that a legal regime is in place that will afford them the opportunity to recover their investment.

But the most straightforward - or perhaps simplistic - explanation of patents as an innovation incentive fails to account for several characteristics of patents as found in practice. First, given the wide range of innovation profiles across various industries, it is not immediately clear how the same statute can prompt the necessary investment under so many varied

3. See generally FTC, To Promote Innovation: The Proper Balance of Competition and Patent Law and Policy (2003), available at http://www.ftc.gov/os/2003 /10/innovationrpt.pdf; Nat'l Research Council, A Patent System for the 21st Century (Stephen A. Merrill et al. eds., 2004).

4. See, e.g., J.E.M. Ag Supply, Inc. v. Pioneer Hi-Bred Int'l, Inc. 534 U.S. 124, $142(2001)$.

5. See infra Section III.A.2.

6. See generally Richard Stern, A Re-examination of Preemption of State Trade Secret Law After Kewanee, 42 GEO. WASH. L. REV. 927, 958 (1974).

7. Id.

8. Robert Mazzoleni \& Richard R. Nelson, The Benefits and Costs of Strong Patent Protection: A Contribution to the Current Debate, 27 RES. POL'y 273 (1998). 
circumstances. ${ }^{9}$ Recent commentary has attempted to offer some perspective as to how the patent system can in fact match incentives to the needs of different industries, but this requires a fairly intricate picture of how different industries experience the patent system and of the institutions that administer the patent system. ${ }^{10}$ Additionally, recent scholarship has also noted that the vast majority of patents appear never to be enforced, or even licensed, as one would expect if they are being used to recoup investments in innovation. ${ }^{11}$ Commentators have suggested that these apparently unused patents are being procured for other business purposes, such as financing, marketing, or strategic advantage. ${ }^{12}$ Extending this insight, other commentators have suggested that patents may play a more complex role in the economics of innovation, lowering transaction costs so as to facilitate more innovative organizational and market structures, rather than simply providing monopoly rents to the holders of exclusive rights. ${ }^{13}$

This emerging body of literature suggests that, as a general matter, the nature and function of the patent system is far more complex, and far more dynamic, than might be predicted by the economics of a neoconservative incentive rationale. This in turn suggests that a reconsideration of the "disclosure" rationale might also be in order: just as a closer examination of the incentive rationale reveals a more complex and nuanced picture than might initially appear, so too a similar reexamination of the disclosure rationale might reveal nuances of the patent system that have gone previously unconsidered. Properly considered, aspects of disclosure or recordation of knowledge might play a more significant role, or at least a more interesting role, in the patent system than the familiar quid pro quo account of patenting might entail.

9. Dan L. Burk \& Mark A. Lemley, Is Patent Law Technology-Specific?, 17 Berkeley TECH. L.J. 1155 (2002); Michael W. Carroll, One for All: The Problem of Uniformity Cost in Intellectual Property Law, 55 AM. U. L. REV. 845 (2006).

10. Dan L. Burk \& Mark A. Lemley, Policy Levers in Patent Law, 89 VA. L. REV. 1575 (2003); Christopher A. Cotropia, "After-Arising" Technologies and Tailoring Patent Scope, 61 N.Y.U. ANN. SURV. AM. L. 151 (2005).

11. Mark A. Lemley, Rational Ignorance at the Patent Office, 95 Nw. U. L. REV. 1495 (2001).

12. Mark A. Lemley, Reconceiving Patents in the Age of Venture Capital, $4 \mathrm{~J}$. SMAll \& EMERGING BuS. L. 137, 137-148 (2000); Ann Bartow, Separating Marketing Innovation From Actual Invention: A Proposal For A New, Improved, Lighter And Better-Tasting Form of Patent Protection, 4 J. SMALL \& EMERGING BUS. L. 1, 2-3 (2000).

13. See Dan L. Burk \& Brett H. McDonnell, The Goldilocks Hypothesis: Balancing Intellectual Property Rights at the Boundary of the Firm, 2007 U. ILL. L. REV. 575; Paul J. Heald, A Transaction Costs Theory of Patent Law, 66 OHIO ST. L.J. 473 (2005); Robert P. Merges, A Transaction View of Property Rights, 20 BERKELEY TECH. L.J. 1477, (2005). 
In this article I suggest one approach to viewing the disclosure rationale from a fresh perspective, by examining the structure and practice of the patent system from the standpoint of knowledge management. In particular, I engage the growing literature regarding tacit and codified knowledge. ${ }^{14}$ I argue that many familiar provisions of the patent statute may be viewed as incentives for codification of otherwise tacit knowledge, and that these provisions either intentionally or unintentionally have effects on the balance of codified and tacit technical knowledge. Controversies over patent doctrines, such as the proper standard for nonobviousness, frequently turn on the degree to which tacit knowledge must be incorporated into the patent system. On this view, the costs and benefits of codification, which have been largely ignored in past debates over the efficacy of patents, should be taken into account in either retaining or reforming the current structure of the patent system.

\section{THE ECONOMICS OF CODIFICATION}

A sizeable body of recent scholarship has examined the dynamics, the qualities, and the incentives attending the collection and preservation of knowledge, most particularly the recordation of knowledge in a stable format. Much of this literature deals with the conditions under which knowledge may be codified, that is, articulated and symbolized so as to be recordable in a particular medium. ${ }^{15}$ One must be a bit careful with this terminology, as lawyers use the term "codify" to refer to the systemization of legal principles. More recently, in some academic circles "code" has become a term of art referring to the technical features, most especially the architectural constraints, attending the structure of computer software. ${ }^{16}$ Each of these uses of the term is related in some degree to the use to which it is put here, but here we are chiefly concerned with the conversion of knowledge to stable symbolic messages. ${ }^{17}$

Recent scholarship has noted the benefits of such codification. For example, one of the primary effects of formal codification is that knowledge becomes separately embodied from human memory. One consequence of such "exteriorization" of the memory is that knowledge becomes detached from individuals, and may be divorced from human transmission. Know-

14. See, e.g., Robin Cowan \& Dominique Foray, The Economics of Codification and the Diffusion of Knowledge, 6 InDUS. \& CORP. CHANGE 595 (1997); Paul A. David \& Dominique Foray, Economic Fundamentals of the Knowledge Society, 1 POL'Y FUTURES IN EDUC. 20 (2003).

15. See Cowan \& Foray, supra note 14, at 603; David \& Foray, supra note 14, at 25.

16. See, e.g., LAWRENCE LeSSig, CODE AND OTHER LAWS OF CYBERSPACE (1999).

17. David \& Foray, supra note 14 , at 25 . 
ledge that is stabilized in a code, rather than is some other medium, takes on durability and tangibility. This in turn implies that codification results in commodification of knowledge, allowing it to be treated more as an object of trade or exchange. ${ }^{18}$ Additionally, inscription of knowledge in a code also allows directed reorganization of knowledge, as the modularity of the recorded information allows it to be isolated, classified, and recombined in new arrangements, regularizing the production of new knowledge. ${ }^{19}$ These qualities of codification will often, but not always, make codification an attractive option for knowledge management.

\section{A. Costs of Codification}

Codification will not always be the preferred option for knowledge management because it entails not only benefits, but significant attendant costs. Codification requires a code, and the development of codes is itself a costly proposition. ${ }^{20}$ Creation of a code, effectively the creation of a language, requires the development of concepts, symbols, and syntax, in addition to the physical media for recordation of the text. ${ }^{21}$ These costs tend to occur as initial or "start-up" fixed costs, with negligible costs for subse-

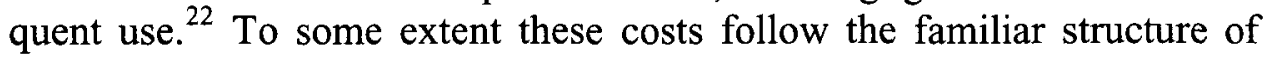
network effects: the positive and negative externalities of goods that generate positive externalities as they are adopted by a larger number of users. ${ }^{23}$ As codes become established and widely adopted, new users can piggy-back onto those existing systems. Additionally, there may be costs to displacing previous codes, as users will have already invested in those systems and will incur new costs in switching to a new code. Such costs can be lowered substantially by using a standardized or widely accepted code.

Additionally, the use of codes may itself impose certain costs. The network effects of codes have a downside; adopting a particular code may "lock in" users to a system from which it is difficult to change when other

18. See Cowan \& Foray, supra note 14.

19. $C f$. Yochai Benkler, The Wealth of Networks: How Social Production TRANSFORMS MARKETS AND FREEDOM 100-103 (2006) (discussing flexible modularity of digital information).

20. See Robin Cowan et al., The Explicit Economics of Knowledge Codification and Tacitness, 9 INDUS. \& CORP. CHANGE 211, 247 (2000); Cowan \& Foray, supra note 14, at 604.

21. See David \& Foray, supra note 14, at 26; Cowan \& Foray, supra note 14 , at 604-05.

22. See Cowan \& Foray, supra note 14 , at $604,612$.

23. See id. at 612-13; see generally Mark A. Lemley \& David McGowan, Legal Implications of Network Economic Effects, 86 CALIF. L. REV. 479 (1998). 
alternatives become available. ${ }^{24}$ And as a corollary, the necessity of promulgating and maintaining a given code will cause organizations to tend toward greater rigidity and uniformity as a natural consequence of supporting a particular system. ${ }^{25}$ Organizations that rely on uncodified knowledge, and so lack the need to maintain the mechanisms of codification, may remain more fluid and entrepreneurial. ${ }^{26}$

\section{B. Tacit Knowledge}

Despite the potential advantages of codification, a certain measure of knowledge will remain uncodified. Some types of knowledge may be inherently uncodifiable because some cognitive capacities resist explicit articulation. ${ }^{27}$ It may be, for example, that if Tiger Woods were asked to write a manual of instructions describing how he drives a golf ball, that he would be unable to define or explain many aspects of his skill. ${ }^{28}$ The precise set of movements and actions that he follows in his golf play may involve some combination of bodily signals, from proprioreceptors to neuromuscular junctions, that simply cannot be explained to another individual. This may be in part because Woods is altogether unaware of the details or components of skills wired into his physiology. Or, it may be that he is aware of his physiological state on some level, but that the sensations and responses cannot be readily described or articulated. ${ }^{29}$

However, much of the knowledge that remains uncodified remains so not because it is inherently impossible to codify, but because it is of a type that is simply too costly to codify. ${ }^{30}$ Indeed, the example of Tiger Woods' golf swing or similarly uncodifiable knowledge might simply be viewed as a limiting case in which codification is infinitely costly. Other types of uncodified knowledge might be codified, but the costs of collecting, encoding, recording, and preserving the information is simply prohibitive given the potential value of the resulting information. ${ }^{31}$ Knowledge of this type will remain uncodified unless the cost of codification falls, or the ex-

24. See Cowan \& Foray, supra note 14 , at $615-16$.

25. See Cowan et al., supra note 20 , at 248.

26. Id.

27. See id. at 228.

28. Cf. Cowan \& Foray, supra note 14, at 606 (analyzing the codification of a description of a tennis serve); RICHARD R. NELSON \& SIDNEY G. WINTER, AN EVOLUTIONARY THEORY OF ECONOMIC CHANGE 77-78 (1982) (analyzing the articulation of instructions on how to land an airplane).

29. NELSON \& WINTER, supra note 28 , at 73.

30. Id. at 80 .

31. See id. 
pected value of the encoded knowledge rises, prompting the investment in codification.

Knowledge that resists codification for either of these reasons remains tacit, that is, not explicitly recorded as a text or similar code. ${ }^{32}$ This is not to say that knowledge which is not codified is necessarily lost, or is inarticulable, or is incommunicable. It is decidedly not to say that knowledge cannot be captured in structures other than a formal code. Tacit knowledge might be conveyed by observation, emulation, or by instinct. ${ }^{33}$ It may potentially be captured, stabilized, and transmitted in structures other than a formal code. We have already suggested that the golf acumen of a Tiger Woods might be transmitted by observation, better recorded on videotape than in textual code. Other tacit knowledge may be captured in institutional practices and procedures, or in normative expectations of behavior. ${ }^{34}$ It may be captured in actual physical structures: whether the design of tools, the arrangements of architectural spaces, or the layout of farm.

Organizational and social systems constitute an especially important reservoir of tacit knowledge. Such knowledge exists in a community, in common practices or norms that are transmitted orally or by example. ${ }^{36}$ Knowledge captured in such practices, although not formally codified, may be stably maintained and transmitted if a pool of acculturated individuals is sustainable. ${ }^{37}$ This presents a somewhat different situation than those in which tacit knowledge is held solely in human memory, as the knowledge is not known by any one individual, but is instead maintained in the interactions between individuals. However, such knowledge may be lost or dissipated, even if known by some, if the relational structure of the group lapses.

Cowan et al. have also identified a range of situations in which knowledge has been codified, but then internalized, so that the code is no longer manifest. ${ }^{38}$ This fairly common process results in situations with a "displaced codebook," where individuals or communities appear to be relying on tacit knowledge but are in fact relying upon previously codified know-

32. See David \& Foray, supra note 14 , at 25 ; see also NeLSON \& WINTER, supra note 28 , at $77-78$.

33. See David \& Foray, supra note 14 , at 25 ,

34. See Cowan \& Foray, supra note 14, at 596-97; Cowan et al., supra note 21 , at 231-36.

35. See Cowan et al., supra note 20, at 229-30; see also Dan L. Burk, Legal and Technical Standards in Digital Rights Management Technology, 74 FORDHAM L. REV. 537, 540-42 (2005) (reviewing literature on inscription of artifacts).

36. See David \& Foray, supra note 14 , at 25.

37. See Cowan \& Foray, supra note 14 , at 601.

38. Cowan et al., supra note 20 , at 230-33. 
ledge that has been internalized. ${ }^{39}$ Examples might include communities where jargon and technical terminology is in common usage, even though it may not be found in an explicit record. Such knowledge may be tacit in the sense that no codified version can be identified, but is not tacit in the sense of being uncodifiable or never codified. Such situations also suggest that knowledge may cycle between codified and tacit, shifting from one form to the other as costs and custom dictate.

\section{Consequences of Codification}

Several consequences follow from these insights regarding the costs and benefits of codification. The first consequence flows from the observation that a great deal of knowledge, perhaps the majority of knowledge, will go uncodified, occasionally because it cannot be codified, but more often because codification is too costly. This means that for any given body of knowledge, the question of codification will not be a binary choice between whether or not to codify. Rather, the question will always be one of how much to codify, and of establishing an equilibrium between codified and uncodified knowledge. ${ }^{40}$

A second and critical corollary that follows from the first is that all codified knowledge will be attended and supported by a constellation of uncodified knowledge. At a minimum, knowledge of how to read the code will remain uncodified ${ }^{41}$; codifying such knowledge leads to an infinite regress that cost will bring to an end at some level of meta-codification. But even codified substantive knowledge will represent only the tip of the knowledge iceberg, supported, buttressed, and amplified by large bodies of uncodified knowledge that as a practical matter cannot or has not been codified.

Given the equilibrium between codified and uncodified knowledge, it also bears mentioning that in some cases the reverse will be true: that tacit knowledge will be supported by codified knowledge. As an example of tacit but captured knowledge, I mentioned above the example of a toolperhaps a golf club-that embodies knowledge about how a certain task is best performed, about interactions with a human user, and perhaps about the nature of the environment or materials that it will be used to manipulate. ${ }^{42}$ But the intended use and advantages of the tool may not be immediately apparent to the potential user. It is fairly common for such a tool to be accompanied by codified instructions and documentation about the

39. Id. at 232 .

40. See Cowan \& Foray, supra note 14 , at $600-01$.

41. Id. at 600 .

42. See Cowan et al., supra note 20 , at 229-30. 
tool, intended to guide the user, and supporting the tacit knowledge embedded in the tool. ${ }^{43}$

A third corollary flows then from the characteristics of codified and uncodified knowledge identified above. Given that some knowledge, and possibly a great deal of knowledge, about a subject will necessarily remain uncodified, and that this knowledge supports and amplifies the codified portions, it will be difficult to move comprehensive knowledge about a topic between settings. We have already seen that codified knowledge, having been separated from human memory, may be more readily moved about, but the uncodified knowledge that supports this codified knowledge moves only with the humans who carry it, or sometimes not at all. In particular, distributed knowledge that has been captured in social structures, organizations, norms and practices may be difficult to move along with the codified items. Thus the availability and feasibility of codification is closely tied to industrial issues such as employee mobility: movement of codified information may be a complement to, rather than a substitute for, the movement of human capital.

\section{PATENTS AND CODIFICATION}

Having sketched a general framework for the incentives and economics of knowledge codification, I turn now to application of that framework to regimes of intellectual property, and most especially patent law. Previous commentators on the economics of knowledge production have noted only in passing some few implications of this framework for intellectual property. Cowan et al. mention the effects of trade secrecy in policing the movement of tacit knowledge ${ }^{44}$ and also the practical effects of patent law's quid pro quo exchange of exclusivity for disclosure. ${ }^{45}$ The first point has implications for the movement of skilled employees in "high velocity" employment markets ${ }^{46}$; the second has implications for the licensing of tacit knowledge that supports the codified knowledge in patents. ${ }^{47}$ Both points are highly significant, although substantially unelabo-

43. Id.

44. Id. at 223-24.

45. Id. at 224.

46. See Alan Hyde, Working in Silicon Valley: Economic and Legal Analysis of a High-Velocity Labor Market (2003); AnnaLee Saxenian, Regional Advantage: Culture and Competition in Silicon Valley and Route 128 (1996); Ronald J. Gilson, The Legal Infrastructure of High Technology Industrial Districts: Silicon Valley, Route 128, and Covenants Not to Compete, 74 N.Y.U. L. Rev. 575 (1999).

47. Ashish Arora \& Robert P. Merges, Specialized Supply Firms, Property Rights, and Firm Boundaries, 13 INDUS. \& CORP. CHANGE 451, 468 (2004). 
rated. Both are closely tied to the growing realization that quite apart from its purposes as an innovation incentive, intellectual property may have important effects on the structure of firms and of industries.

In previous work, I have explored aspects of each of these points, including the effects of intellectual property regimes on the balance of transaction costs internal and external to firms. ${ }^{48}$ Taking into account the effects of codification clarifies certain dimensions of such transaction cost analyses. For example, we have noted above that codification commodifies knowledge, allowing it to be maintained and moved separately from individuals who would otherwise hold it. Conversely, if the knowledge in a firm is not codified, if it remains tacit, then it resides largely with employees. Tacit knowledge may be maintained within a "thick" labor market of workers who move information between firms. ${ }^{49}$ This appears to be the norm in certain "high velocity" employment markets, such as Silicon Valley, where skilled employees move with relative ease between firms. ${ }^{50}$ There would seem to be less incentive for codification where knowledge can be tacitly maintained in the labor force. ${ }^{51}$ But as I detail below, the presence of the patent system may tip the scales toward codified rather than tacit transmission; indeed it may be observed doing so in fields such as software, where the availability of patents is relatively recent compared to the accumulated tacit knowledge in the field.

Thus, combining perspectives from knowledge codification with a detailed understanding of patent law adds an important dimension to these previous studies. Patent law engages the boundary between tacit and codified knowledge at several junctures. Some of these involve the patent document itself as a code, or the incentives to codify knowledge within the patent application, or published patent. Yet other doctrines deal with the balance between codified and tacit knowledge in the technological field of the patented relevant to the patent, that is with the knowledge in the prior art. Yet other aspects of patent law involve the incentives to codify or maintain knowledge regarding the process of invention, or leading to a patentable invention. In the following sections, I review examples of each of these circumstances, and then consider the temporal and institutional issues common to all of them.

48. See Dan L. Burk, Intellectual Property and the Firm, 71 U. CHI. L. REV. 3 (2004); Burk \& McDonnell, supra note 13.

49. See Cowan et al., supra note 20 , at 241.

50. See HYDE, supra note 46 , at 50.

51. See Cowan et al., supra note 20, at 240-41. 


\section{A. Patents as Code}

We begin by considering the purpose and nature of codification in patent documents themselves. As described above, much of the knowledge held in any field of endeavor will be either tacit knowledge, or codified knowledge for which the code book has been displaced. In the patent context, this situation emerges in fields where codified but unrecorded knowledge is ubiquitous. Such situations are manifest as a common complaint among technical personnel in software, or biotechnology, or some other field, that a particular invention must be obvious because "everyone knows" in that field how to make or use the product or the method described in the claims of a patent. ${ }^{52}$ Yet what "everyone knows" may not have been codified into a tangible reference that can be evaluated by a court or by a patent examiner. Failure to codify or record knowledge may occur in fields where codification is unduly expensive for the reasons already identified: lack of an existing code, difficulty of articulation, or similar barriers that make the comparative cost of tacit transmission more attractive.

But these comparative costs of codification may be shifted by the patent system itself, making codification more attractive. This is perhaps most clear in the application of patents to new subject matter since the decision of the United States Court of Appeals for the Federal Circuit in State Street Bank expanded patentable subject matter to any human innovation producing a useful result. ${ }^{53}$ It should not be surprising that much of the concern over the patenting of what "everyone knows" occurs in fields that are not necessarily new themselves, but which are relatively new to the patent system. As the subject matter of patents has expanded, patent law has increasingly moved into areas where codification is difficult or expensive, or where formal codes have otherwise been slow to develop. Returning to the previous example of Tiger Woods's golf prowess, sports moves have now been patented under the permissive subject matter standards articulated by the Federal Circuit. ${ }^{54}$ Certainly "how to" books exist

52. See James Gleick, Patently Absurd, NY Times MagazInE, March 12, 2000, $\$ 6$ (Magazine), at 47.

53. State St. Bank \& Trust Co. v. Signature Fin. Group, Inc., 149 F.3d 1368, 1373 (Fed. Cir. 1998); see also Alan L. Durham, "Useful Arts" in the Information Age, 1999 BYU L. Rev. 1419 (1999); John R. Thomas, The Patenting of the Liberal Professions, 40 B.C. L. REV. 1139 (1999).

54. See, e.g., U.S. Patent No. 6,019,689 (filed May 13, 1998); U.S. Patent No. 5,913,738 (filed Aug. 8, 1997); U.S. Patent No. 5,616,089 (filed Mar. 29, 1996); see also Carl A. Kukkonen, III, Be a Good Sport and Refrain from Using My Patented Putt: Intel- 
for sports training, but much of the knowledge in such fields appears to be passed on orally or via observation, and as suggested above, some such knowledge may be altogether uncodifiable.

Bringing such subject matter into the ambit of patent law potentially moves such codifiable but uncodified knowledge into patent applications. But this requires the development of codes that will carry such knowledge, codes that have presumably gone previously undeveloped because the cost was not worth the trouble. The new possibility of patenting changes that calculus. Thus, the true innovation in such fields may be the articulation of the knowledge and development of a code sufficiently precise to allow codification of the knowledge in a patent application. The patent incentive may spur codification rather than invention.

\section{Patents as Standards}

One benefit of such codification derives naturally from the literature on transaction cost economics mentioned above. Patents themselves incorporate standardized terminology that is recognized by members of the patent drafting community as having an established meaning. Patents may therefore provide a common code for purposes of licensing or similar negotiations. Because of statutory and regulatory requirements, as well as common practice among the community of patent attorneys and agents, the format of a patent is relatively uniform. In licensing negotiations, a licensor dealing with a patented technology typically faces a document that offers a fairly standardized presentation: common jargon, structure, and layout. This may offer a considerable savings over having to examine and interpret idiosyncratic technical documents from different technology holders. Significantly, the licensor is likely to be advised by a patent attorney or agent familiar with the "code" used in patent documents, so that in some sense the patent may offer a common code between members of the patent legal community, who will be translating the code for their clients.

This is not to say that patents are entirely transparent, or that every aspect of a patented technology will be apparent within the four corners of the document. We have seen as a general principle of codification that this is neither possible nor desirable: codified knowledge is always accompanied by, buttressed by, and enabled by tacit knowledge. Consequently, not all the pertinent information regarding an invention will be found in a patent, and indeed patent doctrines recognize this principle. Courts have repeatedly emphasized that patents are not "production specifications," 55

lectual Property Protection for Sports Related Movements, 80 J. PAT. \& TRADEMARK OFF. SOC'Y 808 (1998).

55. See, e.g., In re Gay, 309 F.2d 769, 774 (C.C.P.A. 1962). 
meaning that the inventor need not include every detail of the invention in the disclosure. Rather, the disclosure of the patent relies upon the knowledge of those having skill in the art; the inventor is not required as a matter of patent law to explicitly incorporate into the document commonly held, tacit knowledge.

But neither is the inventor likely to, or required to, include tacit knowledge that is not commonly held. Information specific to the invention will inevitably be left out of the patent disclosure. Such omissions need not necessarily involve any bad faith in the invention disclosure; a full disclosure of the best mode of practicing, say, a claimed production device may not necessarily disclose the organizational structure, spatial positioning, or employee scheduling that will put the device to its fullest use. Sophisticated licensors know that there is a good deal of tacit knowledge behind the codified knowledge in the patent document, and they will negotiate for transfer of that knowledge as well. Licenses routinely include provisions for the transfer, protection, and updating of know-how incident to the patent. But given that the knowledge is tacit, how is a licensor to know what may be available, or whether the licensee is holding out? The patent may provide a concrete point of reference from which potential licensors may extrapolate, or "read between the lines" to determine what other, tacit, information is likely to have been developed. Thus, previous commentators have suggested, the codified knowledge of the patent may be only the starting place for actual negotiations over tacit know-how that is necessary and contextual to make the patented technology function. ${ }^{56}$

\section{Disclosure Provisions}

The expectation that some knowledge will remain tacit, unincorporated in the patent document, and an expectation regarding the proper balance between codified and uncodified knowledge, are implicit in the patent law's disclosure provisions. The patent statute requires a "written description" of the invention-which may include not only text but drawings $^{57}$ - sufficient to enable one of ordinary skill to make and use the claimed invention. ${ }^{58}$ Disclosure of the "best mode" that the inventor knows of practicing the invention is also required. ${ }^{59}$ With regard to written description, it may be worth noting that in the case of plant patents, it was

56. See Ashish Arora, Contracting for Tacit Knowledge: The Provision of Technical Services in Technology Licensing Contracts, 50 J. DEV. ECON. 233, 246 (1996).

57. 35 U.S.C. $\S 112$ (2000); Vas-Cath v. Mahurkar, 935 F.2d 1555, 1565 (Fed. Cir. 1991).

58. 35 U.S.C. $\S 112$.

59. Id. 
decided that the features of ornamental plants may not be amenable to textual description ${ }^{60}$ so that pictures of the plants are substituted in the specification instead - put differently, the type of knowledge needed to specify a plant patent resisted codification, at least symbolic textual codification, so direct observation was needed.

Where textual disclosure is concerned, an issue arises as to what tacit knowledge the hypothetical person having ordinary skill in the art, or "PHOSITA," might bring to bear on the problem of making and using the claimed invention. ${ }^{61}$ The PHOSITA, found in the patent statute, is emblematic of the knowledge held by the community in a given technological field. ${ }^{62}$ The disclosure requirement for patents is couched in terms of the PHOSITA's knowledge. This in turn implicates the tacit knowledge held by the technological community. The explicit disclosure of the patent specification is necessarily embedded in the matrix of information that lies outside the document; it is neither practical nor desirable for the patent disclosure to comprehend the entire technical field. Some information outside the document may be "incorporated by reference"; that is, the patent may refer the reader to other codified references. ${ }^{63}$ But the PHOSITA's ability to make and use the invention described in the patent may also depend upon uncodified information. For example, courts have held that the inventor can rely on the general level of skill in the art to allow the PHOSITA to comprehend and follow the direction of the patent disclosure. ${ }^{64}$ Similarly, the inventor need not specify all the inoperable embodiments that might be encompassed in the claims if the level of skill in the art will allow the PHOSITA to avoid such embodiments of the invention. ${ }^{65}$

Patent disclosure doctrine also addresses the development of codes as a matter of claim definiteness. The inventor is required to communicate the metes and bounds of her invention in formal written claims. ${ }^{66}$ The le-

60. 35 U.S.C. $\S 162(2000)$.

61. 35 U.S.C. $\S 112$.

62. John O. Tresansky, PHOSITA-The Ubiquitous and Enigmatic Person in Patent Law, 73 J. PAT. \& TRADEMARK OfF. SOC'Y 37 (1991); see also ROBERT L. HARMON, PATENTS AND THE FEDERAL CIRCUIT $\S 4.3$ (5th ed. 2001); Joseph P. Meara, Note, Just Who Is the Person Having Ordinary Skill in the Art? Patent Law's Mysterious Personage, 77 WASH. L. REV. 267 (2002). The first known use of the acronym PHOSITA appears to be in Cyril A. Soans, Some Absurd Presumptions in Patent Cases, 10 IDEA 433, 438 (1966).

63. MPEP § 201.17 (2006); 37 C.F.R. $§ 1.57$ (2007).

64. In re Wands, 858 F.2d 731, 735 (Fed. Cir. 1988).

65. Atlas Powder Co. v. E.I. Du Pont de Nemours \& Co., 750 F.2d 1569, 1576 (Fed. Cir. 1984); In re Dinh-Nguyen, 492 F.2d 856, 858-59 (C.C.P.A. 1974).

66. 35 U.S.C. $\S 112(2000)$. 
gal standard requires that the language of the claims must be sufficiently definite to put the reader of ordinary skill on notice as to what technology is encompassed by the patent, warning the reader as to what is off limits. ${ }^{67}$ The doctrine of claim definiteness entails both a public notice function and a rights limiting function. Definite claim language not only warns the public away from the patented technology, it also constrains the inventor from dominating more than she is entitled to; the rights of the patent holder extend to that which is stated in the claims and no more. ${ }^{68}$

In constructing claims, the maxim in patent law is that "the patentee is his own lexicographer," $"$ "that is, that the inventor is free to use whatever language he chooses to describe his invention. He is free to make up new terminology, or to use old terminology in new ways. ${ }^{70}$ The caveat of course is that the language the inventor chooses must be understood by others, so that if the inventor chooses to develop new language, or to repurpose old language, he must define his terminology in that patent. That is to say, he is welcome to develop a new code, so long as he makes the code book available in the published document in which it is used.

We have already noted that the development of codes is costly, so that it is frequently desirable to economize on codification by capitalizing on the positive externalities of established codes. The patentee is also free to go this route, using terminology that is already in use in the pertinent art. ${ }^{71}$ The language of the patent may therefore rely on extrinsic texts: manuals, journals, and textbooks that have separately codified terminology pertinent to the patent. For that matter, the patentee may rely upon uncodified knowledge in use among those of skill in the art. ${ }^{72}$ This will largely be jargon or other knowledge previously codified, for which the codebook has been displaced. ${ }^{73}$ The codebook for such terminology can, if necessary, and at some deferred cost, be attested to by affidavit or testimony at some time subsequent to the drafting of the patent-in other words, production of the codebook can be delayed until the patent is challenged. What is decidedly not permitted is for the inventor to develop the codebook "on the fly" as it were, after the patent has been challenged.

67. Permutit Co. v. Graver Corp., 284 U.S. 52, 60 (1931).

68. General Elec. Co. v. Wabash Appliance Corp., 304 U.S. 364, 369-70 (1938).

69. Merck \& Co., Inc. v. Teva Pharm. USA, Inc., 395 F.3d 1364, 1370 (Fed. Cir. 2005).

70. CCS Fitness, Inc. v. Brunswick Corp., 288 F.3d 1359, 1366 (Fed. Cir. 2002); Elekta Instrument S.A. v. O.U.R. Scientific Int'l, 214 F.3d 1302, 1307 (Fed. Cir. 2000).

71. See Phillips v. AWH Corp., 415 F.3d 1303, 1314 (Fed. Cir. 2005) (en banc).

72. See, e.g., Orthokinetics, Inc. v. Safety Travel Chairs, Inc., 806 F.2d 1565, 157576 (Fed. Cir. 1986).

73. See supra notes $37-38$ and accompanying text. 
However, the patentee who relies upon a displaced codebook, or upon other tacit knowledge, runs the risk that a codebook cannot be produced upon demand, leaving him with undefined terminology and a fatally indefinite patent. This could of course occur simply because of underestimating the cost of generating the codebook. But it is also a risk inherent in relying on tacit knowledge, which is carried by oral transmission or similar mechanisms in a shifting population. As mentioned above, codification has the virtue (or vice) of stability, tacit knowledge has the virtue (or vice) of mutability. By not reducing the needed code to a stable form at an early date, the patentee runs the risk that it may be lost or irretrievably altered by the time the patent is challenged.

\section{B. Tacit Knowledge in the Prior Art}

Patent law also considers the codification of knowledge outside the patent document itself, in related technical literature. In order to qualify for a patent, a claimed invention must meet statutorily defined criteria of novelty ${ }^{74}$ nonobviousness, ${ }^{75}$ and timely application (statutory bar). ${ }^{76}$ These requirements for patentability are defined and assessed according to prior art references that are specified in the statute. Prior art references are specified in terms of a combination of characteristics: by class of reference, by geographic origin, and by critical date. For example, some statutory provisions include within the prior art the public use of the claimed invention, ${ }^{77}$ while others define the prior art in terms of printed publications ${ }^{78}$; some provisions limit the prior art to references published in the United States, ${ }^{79}$ while other provisions include within the prior art references published in foreign countries ${ }^{80}$; some provisions define the prior art as references arising before the date of invention, ${ }^{81}$ while other provisions define the prior art as references arising more than one year before the date an application is filed. ${ }^{82}$ Different combinations of characteristics specify prior art references for different patentability criteria: public uses of the claimed invention in the United States more than one year before the date invention are part of the prior art for novelty but not for statutory bar. ${ }^{83}$

74. 35 U.S.C. $\S 101(2000)$.

75. Id. $\S 103(2000)$.

76. Id. $\S 102$ (2000 \& Supp. II 2002).

77. Id. $\S 102$ (a) (2000).

78. Id. $\S 102(\mathrm{a}),(\mathrm{b})(2000)$.

79. Id. $\S 102(\mathrm{a})$.

80. Id. $\S 102(\mathrm{a}),(\mathrm{b})$.

81. Id. $\S \S 102(\mathrm{a}), 103(\mathrm{a})(2000)$.

82. Id. $\S 102(\mathrm{~b})$.

83. Compare 35 U.S.C. $\S 102(a)$ (2000), with 35 U.S.C. $\S 102$ (b) (2000). 
The statutory criteria for patentability primarily contemplate codified references as constituting their prior art. For example, both the novelty and statutory bar provisions of the statute designate patents and printed publications published prior to their respective critical dates as relevant prior art. ${ }^{84}$ However, the novelty provision also contemplates, at least nominally, tacit knowledge as relevant prior art. If the claimed invention is either "known" or "used" by others besides the inventor in the United States prior to the date of invention, the invention lacks novelty. ${ }^{85}$ Both knowledge and use under this provision appear to include tacit knowledge. The usual rationale for allowing tacit prior art references from within the United States, but not from foreign sources, has been a stability rationale: when the statute was drafted in the nineteenth century, codified information from outside the United States was deemed reliably fixed, whereas tacit knowledge carried from abroad was deemed less reliable. ${ }^{86}$ On this theory, the codification requirement represented an implicit judgment about the stability of knowledge transmission; a higher degree of stabilization was deemed necessary for information circulating internationally, as opposed to that circulating within the United States. Given the changes in mobility and communications technology, one might question whether this judgment still holds in the 21 st Century. ${ }^{87}$

Other statutory sections are less explicit about the types of references against which their requirements will be assessed, but the balance of tacit and codified knowledge is implicit in these standards as well. For example, as in the case of patent disclosure, the obviousness provision of the statute is evaluated against the knowledge base of the statutory PHOSITA. ${ }^{88}$ We have already noted that the PHOSITA is a fictional composite, a conceptual construct imagined for the purpose of assessing the claimed invention against its technological antecedents. ${ }^{89}$ To a large degree, this legal fiction might be said to consist of the explicit references in a technological field; certainly the documents available largely determine how a court constructs the PHOSITA standard in a given instance. For example, the PHOSITA is presumed to know all of the relevant prior art, that is, all

84. Compare 35 U.S.C. $\S 102(a)$, with 35 U.S.C. $\S 102(b)$.

85. 35 U.S.C. $\S 102(a)(2000)$.

86. Donald S. Chisum, Foreign Activity: Its Effect on Patentability Under United States Law, 11 INT'L REV. Indus. Prop. \& COPYRIGHT L. 26, 33-42 (1980).

87. Cf. Margo A. Bagley, Patently Unconstitutional: The Geographical Limitation on Prior Art in a Small World, 87 MINN. L. REV. 679 (2003). But see Craig Allen Nard, In Defense of Geographic Disparity, 88 MINN. L. REV. 221, 224-26 (defending geographic disparities in U.S. patent law on utilitarian grounds).

88. 35 U.S.C. $\S 103$ (2000); Graham v. John Deere Co., 383 U.S. 1, 17 (1966).

89. See supra notes 61-64 and accompanying text. 
of the codified knowledge in the field relevant to the patentability of the claimed invention. ${ }^{90}$

But a recurring theme in the PHOSITA doctrine is the extent to which the knowledge held by those of ordinary skill exists outside the documents that are before an adjudicator. In other words, there is an issue regarding what knowledge held by the PHOSITA may be tacit rather than codified, and how such tacit knowledge can be identified. By its nature, tacit knowledge is difficult to identify and evaluate. A court or other patent evaluator is not expert in the various technological fields that come before it, and knows only what it can see in the documents presented. Although tacit knowledge must clearly be a part, and perhaps an important part, of the skill and knowledge available in a given field, the evaluator can for the most part only rely upon codified knowledge in the evaluation of the technology. Consequently, in order to be evaluated, previously tacit knowledge must become codified, at least to some extent, or remain invisible to an obviousness analysis.

Viewed in this light, the recent controversy over the proper standard for assessing obviousness is similarly grounded in the consideration of tacit and codified knowledge. In its recent decision in KSR, the United States Supreme Court reviewed the nonobviousness standard for patentability. ${ }^{91}$ Unlike the standard for novelty, which requires all the elements of the claimed invention to be found in a single codified reference, the standard for obviousness allows for the combination of references: different characteristics of the invention may be found in separate references that are considered together to determine obviousness. The question is then whether, at the time the inventor combined those characteristics to obtain the claimed invention, it would have been obvious to the PHOSITA to have likewise combined the references. This inquiry is of course simplest if there is some explicit-which is to say codified-suggestion in the prior art that the references could be combined. But more often there is nothing explicit suggesting such a combination. The knowledge that might have led to combination remained unrecorded, tacit, leaving the question of whether tacit knowledge could be identified and relied upon to determine obviousness.

Over its first two and a half decades of patent law decisions, the United States Court of Appeals for the Federal Circuit (CAFC) came down fairly strongly on the side of codified knowledge for determining obvious-

90. In re Rouffett, 149 F.3d 1350, 1357 (Fed. Cir. 1998); In re GPAC Inc., 57 F.3d 1573, 1579 (Fed. Cir. 1995).

91. KSR Int'l Co. v. Teleflex Inc., 127 S. Ct. 1727 (2007). 
ness. The court developed doctrines that entailed a strong preference either for suggestions that were explicit in the prior art, or that constituted a "proven teaching, suggestion, or motivation"; the so-called "TSM" test. ${ }^{92}$ The CAFC's decisions in theory recognized tacit, or implicit suggestions but in fact favored suggestions to combine that had been codified or at most, codified and displaced. The emphasis on codified suggestions of course resulted in a broader swath of inventions being declared nonobvious, as much of the knowledge in a given technology will be tacit, and the lack of recorded suggestions created a default in favor of nonobviousness. This became particularly apparent as patent law moved into new subject matter areas, such as business methods and software, that either did not lend themselves to codification, or which had irregular codification practices.

In reviewing these policies, the Supreme Court's KSR opinion shifted the test for obviousness away from favoring codified knowledge toward greater acceptance of tacit knowledge. The language of the opinion is replete with recognition of the role of tacit knowledge. The Court repudiated the Federal Circuit's emphasis on "precise teachings" instead directed greater consideration of "inferences and creative steps that a person of ordinary skill in the art would employ." 94 The Court noted that "[i]n many fields it may be that there is little discussion [in the literature] of obvious techniques or combinations." "95 The Court held that the Federal Circuit's application of the TSM test "overemphasi[zed] ... the importance of published articles and the explicit content of issued patents." 96 Rather, obviousness analysis should consider the "effects of demands known to the design community or present in the marketplace; and to the background knowledge possessed by a person having ordinary skill in the art." 97

From the standpoint of knowledge management, this standard is in some sense more realistic than the codification-focused standard of the Federal Circuit; the Supreme Court recognized the presence of tacit knowledge among those of skill in the art, directing lower courts to take such knowledge into account in assessing obviousness. But it effectively trades a more complete account of knowledge in the prior art for the problems that attend determination of tacit knowledge. As I shall take up in greater

\author{
92. Id. at 1734 . \\ 93. Id. at 1741 . \\ 94. Id. \\ 95. Id. \\ 96. Id. \\ 97. Id. at 1731 (emphasis added).
}


detail below, reliance upon tacit knowledge creates certain practical and institutional problems as to how an adjudicator can take into account knowledge that has not been reduced to a stable, accessible form. ${ }^{98}$

\section{Codifying Conception}

In addition to affecting the patent itself and the associated prior art, patent law impacts the codification of knowledge related to the inventive process. Under the first-to-invent system currently employed by the United States, a conflict between multiple claimants applying for a patent on the same technology is resolved according to proof of earliest inventive activity. ${ }^{99}$ In most of the world, such a conflict would be resolved in favor of the earliest applicant as established by the receipt of a patent application at the patent examining office. But in the United States, priority of application is only one piece of evidence considered in awarding the patent; a later applicant, or "junior party" may receive the patent by demonstrating the earliest evidence of invention. Generally, conception, or mental formation of the invention's design, ${ }^{100}$ is the key event determining priority of invention, although the reduction to practice of the invention and the diligence of a junior party in reducing the invention to practice also bear on the question of priority. ${ }^{101}$

This method of awarding a patent ultimately requires a type of proceeding, the interference, by which the Patent Office collects and evaluates temporal evidence of invention. ${ }^{102}$ Such a proceeding necessarily implicates matters of knowledge codification. The patent application itself provides a record of inventive activity, so the date of application provides a starting point for considering priority. The application also establishes constructive reduction to practice, on the theory that the application contains the necessary information to allow one of ordinary skill to make and use the invention, even if no one has ever actually done so. ${ }^{103}$

But if activity prior to the date of application is to be relied upon, there must be some record of that activity. Although conception is essentially a mental act, the Patent Office cannot realistically evaluate a purely mental act; it can evaluate only a record of that act. Thus, conception, for example, may be established by detailed documents recorded contemporaneous-

98. See infra notes 109-114 and accompanying text.

99. 35 U.S.C. $\S 102(\mathrm{~g})(1)(2000)$.

100. Singh v. Brake, 222 F.3d 1362, 1367 (Fed. Cir. 2000).

101. Id. at 1370.

102. See 35 U.S.C. $\S 135(a)$, (b) (2000); 37 C.F.R. $\S \S 1.607-1.608$ (2004).

103. See Porter v. Louden, 7 App. D.C. 64,70 (1895). 
ly with the date they are intended to establish. ${ }^{104}$ Some aspects of invention might be established by codification of knowledge after the fact, through interrogatories or deposition of testimonial evidence, ${ }^{105}$ but the evidentiary core of conception requires contemporaneous codification of the inventions claimed characteristics. ${ }^{106}$ To some extent, the same is true of the other activities, such as diligence and reduction to practice, that bear upon the process of invention. ${ }^{107}$ This means that, unlike other countries where the patent application priority is based upon the receipt of the patent application alone, in the United States, priority is ultimately based upon other codified references that can be evaluated by the Patent Office.

Priority of invention may also be used offensively, rather than defensively, that is, to challenge the validity of a patent rather than to establish a claim to a patent. An existing patent may be challenged by showing that the recipient was not the first inventor, but rather that someone else was. In the United States, such a challenge would be brought in court, making a court rather than the Patent Office the institution to evaluate the evidence of inventive activity. But invention would be established by the same events: conception, reduction to practice, and diligence; and the need for recorded evidence of those events would be the same. ${ }^{108}$

The first-to-invent system thus creates its own set of incentives for codification. For example, in anticipation of a possible priority contest, most well-informed research and development operations have in place a system of contemporaneous recordkeeping, including witnessed and countersigned research documents that could be used to establish the dates of conception for patentable technologies. Good scientific and engineering practice dictates the maintenance of notebooks and research logs, but the demands of proving patent priority go well past standard research practice. The recording, witnessing, dating, and countersigning of research notebooks and other documents is costly, if only in the recordkeeping burden that it places upon research personnel.

Such expenditures are not necessarily a bad practice. Although costly, more meticulous laboratory practice and recordation might be regarded as a social benefit, in this case prompted by the patent system. The first-toinvent system may be viewed as rewarding early codification of technical

104. See Gould v. Schawlow, 363 F.2d 908, 911-12 (C.C.P.A. 1966).

105. See Gianladis v. Kass, 324 F.2d 322, 326-27 (C.C.P.A. 1963).

106. See Mahurkar v. C.R. Bard, Inc., 79 F.3d 1572, 1577-78 (Fed. Cir. 1996); Price v. Symsek, 988 F.2d 1187, 1194-95 (Fed. Cir. 1993).

107. 37 C.F.R. $§ 41.204(a)(2)$ (2007); Mikus v. Wachtel, 504 F.2d 1150, 1151 (C.C.P.A. 1974)

108. 35 U.S.C. $\$ 102(\mathrm{~g})(2)(2000)$. 
knowledge, and this may be a desirable outcome if independent stabilization and transmission of knowledge is an important social goal. However, the codification expenditures prompted by the need to safeguard patent priority may possibly be wasteful if knowledge in the field is better held or transmitted in other, tacit stabilizing structures. As noted previously, some knowledge will always remain tacit, but the potential for obtaining a patent - or, perhaps more to the point, the threat of losing a patent in a priority contest-shifts the boundary of tacit and codified knowledge within a given innovation project.

\section{EVIDENTIARY CODIFICATION}

A common theme running through the patent doctrines considered above is one of timing and venue for codification. For example, we have noted that section 102(a) of the patent statute contemplates uncodified novelty references, and that the PHOSITA standard for nonobviousness and enablement may take tacit knowledge into account. ${ }^{109}$ However, ironically, in order for either the Patent Office or a court to evaluate such tacit knowledge, some degree of codification must occur; there must be a written reference for the decision maker to evaluate at the time a patent application is examined or an issued patent is challenged. Tacit knowledge must be identified and recorded as an affidavit, deposition, or similar document. Thus the existence of, say, a novelty reference as tacit rather than codified knowledge is primarily a temporal question: the ostensibly tacit prior art categories in the novelty provisions are in fact directed to knowledge that was tacit at the time of invention, but which necessarily becomes codified by the time of evaluation. This in turn means that institutional review of the references is dependent upon the cost of codifying tacit knowledge; the references that will be assessed in determining novelty are those for which some investment was made in codification.

Such codification investments turn on the applicable incentives. Some references may be too expensive to codify, for reasons indicated above: there may be no existing code, the references may not be the type of knowledge easily codified, or the search costs to locate the uncodified knowledge will be too high. The comparative advantage that might prompt location and codification of such knowledge may of course arise out of the value to be gained by challenging the patent, or in some cases, to be gained in successfully defending the patent. The prospect of challenging a patent may therefore create an incentive toward codification of certain references. Some commentators have argued that more valuable patents are

109. See supra notes $63-65,84-87,93-98$ and accompanying text. 
more likely to be challenged ${ }^{110}$; the corollary may be that more valuable patents are, especially if challenged, more likely to prompt codification of tacit information associated with that technology.

While evaluation or adjudication of patents requires codification of knowledge, tacit knowledge remains an integral part of evaluation or adjudication. An evaluating or adjudicatory body for the most part relies upon codified knowledge. Some institutions, primarily the courts, have developed processes for considering oral testimony-although even oral testimony is transcribed. But much of the deference paid to courts in appellate review of factual findings relies upon the expectation that a good deal of important knowledge about witnesses and evidence will remain untranscribed, tacit, and so unreviewable on an appellate record. Patent examiners may also rely on some tacit knowledge, informally, to the extent that this is conveyed in examiner interviews-and they receive no real deference for such tacit input under current appellate practice. At least part of the controversy over the agency status of the USPTO in appellate review ${ }^{111}$ might be considered in such terms; while the controversy has been cast in terms of the agency's expertise in identifying and evaluating codified knowledge, ${ }^{112}$ it could be thought of in terms of the uncodified knowledge that the agency considers and which is not or cannot be conveyed to a reviewing court in an appellate record. ${ }^{113}$

This recognition leads to some important questions of institutional design. While certain aspects of patent office practice, such as interference practice, entail deposition and similar oral discovery mechanisms, the ex parte USPTO examination process lacks most of the processes that exist in trial courts for developing codified knowledge. An examiner is largely dependent on the applicant to codify necessary tacit knowledge in the form of affidavits or similar documents. The existence of codification mechanisms in the court system is of course one of the reasons that litigation is costly: codification is a costly process. Were similar mechanisms to be incorporated into the examination process, for example in the form of inter partes intervention in the patent application process, the cost of the examination process would necessarily increase.

The necessity of creating a stable documentary record for appellate review is of course not unique to patent prosecution - this is to some extent a common problem in creating an evidentiary record in any adjudication.

110. Lemley, supra note 11 , at 1527.

111. See Dickinson v. Zurko, 527 U.S. 150, 154 (1999).

112. See Stuart Minor Benjamin \& Arti K. Rai, Who's Afraid of the APA? What the Patent System Can Learn from Administrative Law, 95 GEO. L.J. 269, 309-10 (2007).

113. See In re Lee, 277 F.3d 1338, 1344-45 (Fed. Cir. 2002). 
But it is a particular problem in patent law where the statute requires evaluations to be made against the sum of knowledge in entire technological fields. The lack of codified knowledge presents an ongoing problem in the Patent Office, where examiners may make a patentability determination relying on their own expertise in a field rather than on an explicit reference. Some provision is made for examiners to rely on their personal knowledge of the art, but such reliance requires codification of that knowledge as an affidavit. ${ }^{114}$ Examiners are technically trained, but the technical training of examiners seems intended to only direct them in finding and recognizing codified references, and not to incorporate into their examination whatever tacit knowledge they may share with the rest of their technical community. ${ }^{115}$

\section{CODIFICATION AND PATENT REFORM}

The questions of institutional design raised by a codification perspective lead naturally to consideration of what insights this approach might offer on matters of patent reform, and related considerations for small or entrepreneurial innovators. To date, proposals for patent reform have been largely driven by concerns over the costs of litigation, or over costs arising from the potential for litigation when firms are threatened by patent holders. ${ }^{116}$ Other adjudicatory costs, such as those for interferences, prompt similar concerns.

But costs of adjudication are not the whole picture, and when taken in context may not even be the most significant part of the picture. An illustration from another field provides a useful parallel. Commentators analyzing the social impact of nuclear weapons technologies have pointed out that while the consequences of actually using nuclear weapons would of course be staggering, focusing on the use of such weapons or even the threat of using such weapons may hide their real social costs. ${ }^{117}$ Even unused, the cumulative social and economic costs of developing, maintaining, and controlling such weapons is extremely significant, and is incurred on a daily basis so long as the weapons systems exist. In particular, main-

114. 37 C.F.R. $\S 1.104(d)(2)(2007)$.

115. In re Lee, 277 F.3d at 1345.

116. See James Bessen \& Michael J. Meurer, Patent Failure: How Judges, Bureaucrats, and Lawyers Put Innovation at Risk 130-44 (2008).

117. Donald A. MacKenzie, Inventing Accuracy: A Historical Sociology of Nuclear Missile Guidance 382-409 (1st ed. 1990). 
taining the organizational structures that support the tacit knowledge for nuclear command and control is a significant ongoing cost. ${ }^{118}$

Similarly, patent litigation is extraordinarily expensive, and even the threat of litigation creates very significant business expenses. ${ }^{119}$ However, as mentioned above, the vast majority of patents are never used for this purpose, and patent litigation is in fact a relatively rare event in the patent system. Given the astronomical costs of litigation when it occurs, it is perhaps not surprising that reform tends to focus on those costs, or the costs incurred in anticipation of litigation. But such a focus may allow relatively rare, if monumental, costs to overshadow other systemic costs, as well as the tradeoff between such systemic costs and their associated benefits.

A somewhat different picture may emerge when effects such as codification costs are taken into account. To choose only one example mentioned above, the ongoing costs in large research departments of maintaining codification systems to document conception of an invention can be quite significant. Despite the burden on researchers, most large research and development operations tend to have some invention and disclosure protocols in place in anticipation of future priority disputes. Where smaller, entrepreneurial firms are concerned, the costs of implementing such procedures may be prohibitive; lacking the infrastructure to record and maintain proof of conception, smaller firms may elect simply to risk losing a hypothetical interference that may never occur.

Shifting away from a first-to-invent system eliminates the potential costs of an interference by tying patent ownership to the production of a particular document: the patent application. It has been argued that this favors larger firms with the resources to rapidly produce such documents. ${ }^{120}$ But a first-to-file system would also eliminate a significant burden on larger research firms in the form of institutional requirements for recording the process of conception and reduction to practice. At the same time, eliminating such recordkeeping may level the playing field between

118. See Donald MacKenzie \& Graham Spinardi, Tacit Knowledge, Weapons Design, and the Uninvention of Nuclear Weapons, 101 AM. J. SOCIOLOGY 44, 67-75 (1995).

119. See BESSEN \& MEURER, supra note 116, at 130-33.

120. See, e.g., Patent Harmonization: Hearing Before the Subcomm. on Courts, the Internet, and Intellectual Prop. of the H. Comm. on the Judiciary, 109th Cong. 55 (2006) (prepared statement of Pat Choate, Political Economist and Author of "Hot Property: The Stealing of Ideas in an Age of Globalization"); FTC, A SUMMARY REPORT OF DISCUSSIONS AT TOWN MEETINGS ON PATENT REFORM 8-9 (May 2005), available at http:// www.ftc.gov/opp/intellect/050601summarytownmtg.pdf; see also Skip Kaltenheuser, Small Business Innovators See Proposed Patent System as Threat, PANDAB, June, 1998, http://www.pandab.org/small-business-innovators.html. 
large and small firms by removing an advantage that larger organizations would enjoy in anticipation of interferences.

This perspective suggests that adoption of a first-to-file system, which has been sometimes opposed as a detriment to small firms, might in fact benefit them by taking away the comparative advantage of larger firms in recordkeeping. ${ }^{121}$ At the same time, as I have pointed out above, if a firstto-invent system creates an incentive to record knowledge about technological development, effectively reinforcing good laboratory practice, society might lose the corresponding benefits of detailed recordkeeping prompted by the threat of a future interference. Neither of these effects, good or bad, has been discussed in the debate over whether to abandon a first-to-invent system in the United States. This in turn suggests that when effects such as codification are taken into account, the calculus of costs and benefits in patent reform may be more complex than might be assumed under the familiar view that patents provide-or don't provideincentives to technologically innovate.

\section{CONCLUSION}

In recent work I have argued that the social role of patents is not fully captured by economic analysis, ${ }^{122}$ even though that has been the prevailing, and almost exclusive, method for legal scholars examining the field. Here I suggest that even within the economic analytical paradigm, there is a good deal that may have been overlooked. Unexpected, unintended, subsidiary, or alternative effects are an important part of the calculus of patent costs and benefits. By considering the patent system as a system of knowledge management and codification, it becomes apparent that patents generate a large range of incentives, not necessarily oriented toward the kinds of technological innovation that have been the focus of patent scholarship.

121. Cf. Mark A. Lemley \& Colleen V. Chien, Are the U.S. Patent Priority Rules Really Necessary?, 54 HASTINGS L.J. 1299, 1323 (2003) (noting that interferences are most frequently used by large entities to challenge priority of smaller entities).

122. See Dan L. Burk, Feminism and Dualism in Intellectual Property Law, 14 J. GENDER SOC. POL'Y \& L. 183 (2007). 